Synthesis of Natural

Products and

Potential Drugs

\section{Total Synthesis of $(+)$-Cavicularin}

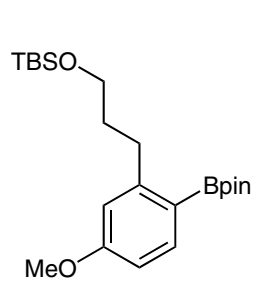

A

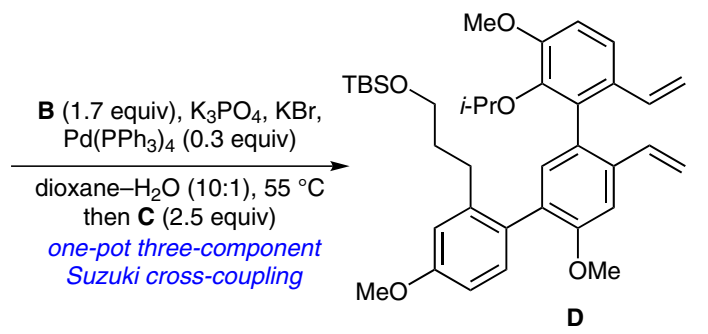<smiles>C=Cc1cc(Br)c(Br)cc1Br</smiles>

B<smiles>C=Cc1ccc(OC)c(OCCC)c1Br</smiles><smiles>CCCCC(C)C(=O)O</smiles><smiles></smiles><smiles>COc1ccc(CC/C=C/OSc2ccccc2)c(-c2cc3c(cc2OC)CCc2ccc(O)c(Oc4ccccc4O)c2-3)c1</smiles>

E
Key words

(+)-cavicularin coupling

pyrone Diels-Alder reaction

\section{SYNFACTrenth}

Suzuki cross-
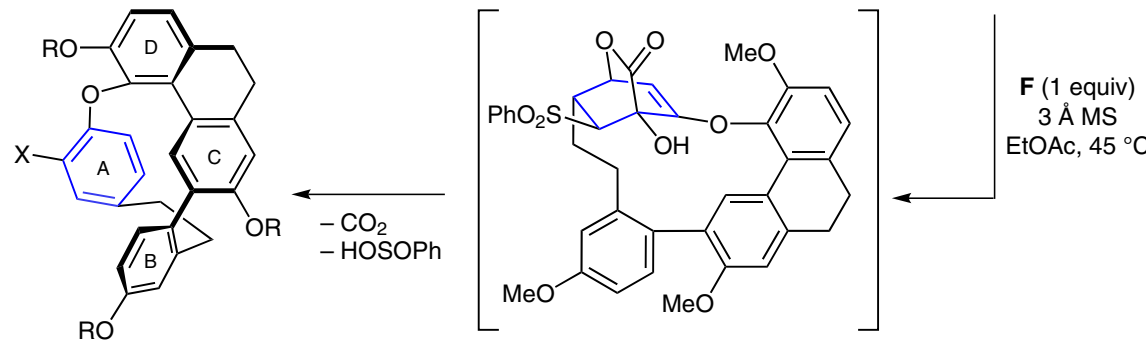

$$
\begin{array}{ll} 
& \mathbf{H}: \mathrm{R}=\mathrm{Me}, \mathrm{X}=\mathrm{OH} \longrightarrow \begin{array}{r}
\mathrm{Tf}_{2} \mathrm{O}, \mathrm{CH}_{2} \mathrm{Cl}_{2}, 0^{\circ} \mathrm{C} \\
45 \% \text { from } \mathrm{E}, \mathrm{er}=89: 11
\end{array} \\
\begin{array}{l}
\text { 1. } \mathrm{NH}_{4} \mathrm{HCOO}, \mathrm{Pd} / \mathrm{C} \\
\mathrm{MeOH}, 70{ }^{\circ} \mathrm{C} \\
\text { 2. } \mathrm{BBr}_{3}, \mathrm{CH}_{2} \mathrm{Cl}_{2}, 80 \% \\
\text { from I }
\end{array} \quad \begin{array}{l}
\text { (+)-Cavicularin: } \\
\mathrm{R}=\mathrm{X}=\mathrm{H}
\end{array}
\end{array}
$$

Significance: (+)-Cavicularin, isolated from the liverwort Cavicularia densa, is a chiral cyclophane natural product. Because of its unusual molecular structure, several total syntheses have been reported to date. Zhao and Beaudry report a conceptionally different approach, which relies on an intramolecular enantioselective pyrone Diels-Alder reaction with subsequent $\mathrm{CO}_{2}$ extrusion to generate the aromatic $\mathrm{A}$ ring of the natural product.
Comment: The synthesis commences with a remarkably selective one-pot three-component Suzuki cross-coupling between dibromide B and boronic esters $\mathbf{A}$ and $\mathbf{C}$. Coupling product $\mathbf{D}$ was further advanced to $\alpha$-hydroxy pyrone $\mathbf{E}$. In the presence of cinchona alkaloid $\mathbf{F}$, this material underwent the desired Diels-Alder reaction to yield intermediate $\mathbf{G}$, which immediately eliminated $\mathrm{CO}_{2}$ and phenylsufinic acid to generate $\mathbf{H}$ as a single regioisomer. Finally, reduction and protecting group removal yielded (+)-cavicularin in $7.3 \%$ overall yield. 